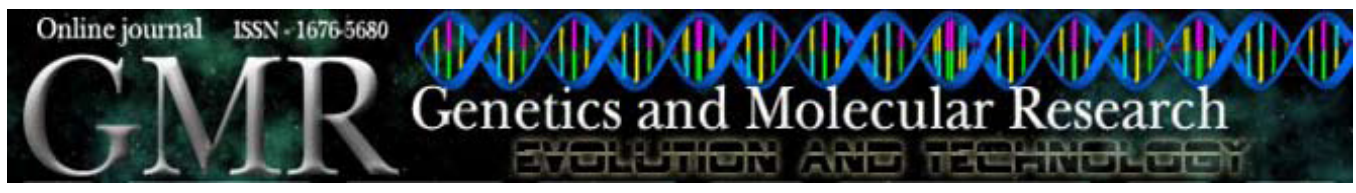

\title{
The investigation of DNA repair polymorphisms with histopathological characteristics and hormone receptors in a group of Brazilian women with breast cancer
}

\author{
R.M. Dufloth ${ }^{1}$, A. Arruda ${ }^{2}$, J.K.R. Heinrich ${ }^{3}$, F. Schmitt ${ }^{4}$ \\ and L.C. Zeferino ${ }^{2}$ \\ ${ }^{1}$ Departamento de Pathologia, Universidade Federal de Santa Catarina, \\ Florianópolis, SC, Brasil \\ ${ }^{2}$ Departamento de Ginecologia e Obstetrícia, \\ Universidade Estadual de Campinas, Campinas, SP, Brasil \\ ${ }^{3}$ Centro de Atenção Integral à Saúde da Mulher, \\ Universidade Estadual de Campinas, Campinas, SP, Brasil \\ ${ }^{4}$ Faculdade de Medicina, Instituto de Patologia e Imunologia Molecular, \\ Universidade do Porto, Porto, Portugal \\ Corresponding author: R.M. Dufloth \\ E-mail: rozany.ufsc@gmail.com
}

Genet. Mol. Res. 7 (3): 574-582 (2008)

Received April 15, 2008

Accepted June 16, 2008

Published July 1, 2008

\begin{abstract}
The association of tumor differentiation and estrogen receptor expression with the prognosis of breast cancer has been well established. Nevertheless, little is yet reported about the association of morphological characteristics of the tumor, estrogen receptor status and polymorphisms in low penetrance genes. The aim of the present study was to investigate a possible association between DNA repair gene polymorphisms (XRCC1, XPD, XRCC3, and $R A D 51)$ with histological type, grade and hormone receptor expression in a series of breast cancers. A cross-sectional study was carried out to evaluate 94 women with breast carcinoma, who had already
\end{abstract}


been selected and included in a study on the association of DNA repair gene polymorphisms. For immunohistochemistry, formalinfixed, paraffin-embedded tissue samples from breast tumors were consecutively retrieved from the histopathology files of our institution. DNA obtained from blood samples of the same patients was investigated for the presence of the following polymorphisms: Arg399 Gln located in the XRCC 1 gene; $135 \mathrm{C} / \mathrm{G}$ located in the $R A D 51$ gene; Lys $751 \mathrm{Gln}$ located in the XPD gene and Thr241Met located in the $X R C C 3$ gene. Polymorphisms were considered to be independent variables and hormone receptor expression and the morphological characteristics of the tumors comprised the dependent variables. No statistically significant association was found between gene polymorphisms and hormone receptor status. The association between XRCC1-Arg399Gln polymorphism and ductal carcinoma was statistically significant $(\mathrm{P}=0.02)$. The association of the $X P D$ Lys $751 \mathrm{Gln}$ polymorphism with histological grade was also statistically significant $(\mathrm{P}=0.05)$. In conclusion, the $X R C C 1$ genotype was found to be associated with ductal carcinoma histotypes and $X P D$ genotype with low histological grade, which is the most frequent pattern of sporadic breast carcinomas.

Key words: Breast cancer; Estrogen; Polymorphisms; Hereditary disease

\section{INTRODUCTION}

Genetic alterations in low-penetrance genes have been possibly related to cancer susceptibility within an interactive context with several factors related to lifestyle and also endogenous and environmental factors. This interaction could elicit the occurrence of the majority of the sporadic cancers of the breast (Johnson-Thompson and Guthrie, 2000). Hereditary breast cancer generally initiates earlier and is frequently multifocal or bilateral, while sporadic cancer is in general unilateral and appears at a more advanced age (Rebbeck, 1999).

Histopathological studies have disclosed that $B R C A 1$ and $B R C A 2$ mutant tumors have a high nuclear polymorphism rate and lesser formation of ducts in comparison to the non-BRCA-mutant breast tumors (Lakhani et al., 1998; Lakhani, 1999). However, it is not known if polymorphisms in genes that can be associated with high susceptibility of breast cancer can also be associated with different morphologic characteristics of the neoplasia.

Estrogen, as well as other hormones, participate in the carcinogenic process in the promotion phase, when expansion of mutated cell clones occurs. For this regard, this hormone stimulates some growth factors: epidermal growth factor, transforming growth factor- $\alpha$, insulin-like growth factors I and II, and fibroblastic growth factor. The estrogen receptors (ER) are proteins that are part of the family of steroid receptors. There are more than two types of ER, but the main ones are the $\alpha$ and $\beta$ types. The most well known and studied is ER- $\alpha$, which predominates in mammary carcinoma cells. ER- $\beta$ was described 
recently and is frequently present in the normal breast (Dowsett and Ashworth, 2003; Murphy et al., 2003). In order to be functionally active, estrogen crosses the membrane of the target cell by passive diffusion and links to its receptor in the nucleus. The hormonereceptor complex, which has a great affinity for DNA, starts to control the speed of transcription of several genes. This interaction modifies the proteins involved in the regulation of cell differentiation and proliferation, triggering important changes in the synthesis of mRNA (Murphy et al., 2003).

Although oophorectomy in pre-menopausal women diminishes the risk for breast cancer in BRCA1-mutant women, about $70 \%$ of the cases arising in this setting are ERnegative (Gruvberger et al., 2001; Althuis et al., 2004). These data contrast with the fact that sporadic breast tumors are ER-positive (Noruzinia et al., 2005). The correlation between $B R C A 1$ mutation and ER-negative breast cancer is an intrinsic property of $B R C A 1$ cancers and not a consequence of the young age of onset or the tumor with high histological grade (Foulks et al., 2004).

However, it is not known if patients with different profiles of ER expression might present a positive association with or even might be subtyped according to their gene polymorphism profiles specially those related to high susceptibility for breast cancer. Therefore, we expanded our previous study (Dufloth et al., 2005) on the association of genetic polymorphisms, $X R C C 1, X P D, X R C C 3$, and $R A D 51$, in a group of Brazilian women with breast cancer in an attempt to investigate the existence of an association of these polymorphisms with histological type, grade and hormone expression in breast cancer. The results of this study will help us to better understand the role of different DNA repair gene polymorphisms and their synergistic contribution along with histo- and morphological tumor characteristics for the molecular characterization of breast cancers in terms of risk, susceptibility and in a long run for treatment management and prognosis.

\section{MATERIAL AND METHODS}

\section{Patient selection}

The study analyzed 94 women with breast cancer who had already been selected and included in a previous study on the association of susceptibility to breast cancer and DNA repair gene polymorphisms (XRCC1,XPD, XRCC3, and RAD51) (Dufloth et al., 2005). All patients signed an informed consent form prior to sample collection (blood collection and formalin-fixed, paraffin-embedded tissue retrieval). The study protocol was approved by the Internal Review Board of the Universidade Estadual de Campinas (UNICAMP).

\section{Genotyping}

DNA from blood was extracted by standard phenol-chloroform techniques for polymorphism analysis. All polymorphisms were assessed using the polymerase chain reaction-restriction fragment length polymorphism (PCR-RFLP) technique. PCR followed by enzymatic digestion (RFLP) was used for genotyping the XRCC1-Arg399Gln, XPD-Lys 751Gln, XRCC3Thr241Met, and RAD51-G135C polymorphisms. All PCR products were carried out in a total 
reaction volume of $50 \mu \mathrm{L}$ containing nearly $100 \mathrm{ng}$ genomic DNA, 1 U Taq polymerase in $1 \mathrm{X}$ PCR buffer, $1.5 \mathrm{mM} \mathrm{MgCl}, 0.2 \mathrm{mM}$ dNTPs, and $0.20 \mu \mathrm{M}$ of each primer. Thermal cycling conditions were as follows: initial denaturation step at $95^{\circ} \mathrm{C}$ for $3 \mathrm{~min}, 35$ cycles of PCR consisting of $95^{\circ} \mathrm{C}$ for $30 \mathrm{~s}, 60^{\circ}, 55^{\circ}, 60^{\circ}$, and $53^{\circ} \mathrm{C}$ for $30 \mathrm{~s}$ for $X P D, X R C C 1, X R C C 3$, and $R A D 51$ genes, respectively, and $72^{\circ} \mathrm{C}$ for $30 \mathrm{~s}$, followed by a final extension step at $72^{\circ} \mathrm{C}$ for $10 \mathrm{~min}$. The XPD-Lys 751Gln polymorphism resulted in a 161-bp PCR product which was digested with PstI. The digestion resulted in 41- and 120-bp fragments corresponding to the Gln 751 allelic variant or a 161-bp fragment containing the Lys 751 allele. The XRCC1-Arg399Gln resulted in a 248-bp PCR product which was digested with NciI. The Arg399 allele was represented by fragments of 89 and $159 \mathrm{bp}$, and the $G \ln 399$ allele (variant allele) was not digested. The XRCC3-Thr241Met polymorphism resulted in a 136-bp PCR product. This was digested with $N c o$ I. The Thr241 allele was represented by 39- and 97-bp fragments, and the Met241 allele (variant allele) was not digested. The $R A D 51-G 135 C$ polymorphism product was a 157-bp PCR product. This was digested with $M v a I$. The digestion resulted in 86- and 71-bp fragments corresponding to the $G 135$ allele, or a 161-bp fragment representing the $C 135$ allele (variant allele). The PCR products were visualized by electrophoresis on a $2 \%$ agarose gel, and the digestion products were visualized by electrophoresis on a 3\% agarose gel. PCR followed by enzymatic digestion was performed for genotyping the XRCC1-Arg399Gln, RAD51-G135C, XPD-Lys 751Gln, and XRCC3-Thr241Met polymorphisms.

Summarized conditions and selected primers for PCR and RFLP are presented in Table 1.

Table 1. Primers, amplification parameters and polymerase chain reaction (PCR) product fragment size used as PCR conditions, and specific restriction enzymes and corresponding digestion product fragment size used as restriction fragment length polymorphism (RFLP) conditions, for the polymorphisms studied.

\begin{tabular}{|c|c|c|c|c|}
\hline \multirow[t]{2}{*}{ PCR conditions } & \multicolumn{4}{|c|}{ Polymorphism } \\
\hline & XRCC1-Arg399Gln & XPD-Lys $751 G l n$ & $R A D 51-G 135 C$ & XRCC3-Thr241Met \\
\hline Forward & $\begin{array}{l}\text { 5'-CAA GTA CAG } \\
\text { CCA GGT CCT AG-3' }\end{array}$ & $\begin{array}{l}\text { 5'-CTG CTC AGC } \\
\text { CTG GAG CAG CTA } \\
\text { GAA TCA GAG GAG } \\
\text { ACG CTG-3' }\end{array}$ & $\begin{array}{l}\text { 5'-TGG GAA } \\
\text { CTG CAA CTC } \\
\text { ATC TGG-3' }\end{array}$ & $\begin{array}{l}\text { 5'-GCC TGG } \\
\text { TGG TCA TCG } \\
\text { ACT C-3' }\end{array}$ \\
\hline Reverse & $\begin{array}{l}\text { 5'-CCT TCC CTC } \\
\text { ATC TGG } \\
\text { AGT AC-3' }\end{array}$ & $\begin{array}{l}\text { 5'-AAG ACC } \\
\text { TTC TAG CAC } \\
\text { CAC CG-3' }\end{array}$ & $\begin{array}{l}\text { 5'-GCG CTC } \\
\text { CTC TCT CCA } \\
\text { GCA G-3' }\end{array}$ & $\begin{array}{l}\text { 5'-ACA GGG } \\
\text { CTC TGG AAG } \\
\text { GCA CTG CTC } \\
\text { AGC TCA CGC } \\
\text { ACC-3' }\end{array}$ \\
\hline $\begin{array}{l}\text { Annealing temperature } \\
\text { Number of cycles } \\
\text { PCR product (bp) }\end{array}$ & $\begin{array}{l}58^{\circ} \mathrm{C} / 30 \mathrm{~s} \\
32 \\
268\end{array}$ & $\begin{array}{c}60^{\circ} \mathrm{C} / 30 \mathrm{~s} \\
32 \\
161\end{array}$ & $\begin{array}{c}53^{\circ} \mathrm{C} / 30 \mathrm{~s} \\
32 \\
159\end{array}$ & $\begin{array}{c}60^{\circ} \mathrm{C} / 30 \mathrm{~s} \\
32 \\
136\end{array}$ \\
\hline \multicolumn{5}{|l|}{ RFLP conditions } \\
\hline Restriction enzyme & $B c n I$ (Fermentas) & Pst I (Fermentas) & MvaIII (Fermentas) & $\begin{array}{l}\text { NlaIII } \\
\text { (New England Biolabs) }\end{array}$ \\
\hline \multicolumn{5}{|l|}{ Digestion products (bp) } \\
\hline $\begin{array}{l}\mathrm{W} \\
\mathrm{M}\end{array}$ & $\begin{array}{l}91 \text { and } 177 \\
268\end{array}$ & $\begin{array}{c}161 \\
41 \text { and } 120\end{array}$ & $\begin{array}{c}71 \text { and } 88 \\
159\end{array}$ & $\begin{array}{c}136 \\
35 \text { and } 101\end{array}$ \\
\hline
\end{tabular}

$\mathrm{W}=$ common allele; $\mathrm{M}=$ rare allele . 


\section{Immunohistochemistry}

Formalin-fixed, paraffin-embedded samples from 94 breast tumor patients were consecutively retrieved from the histopathology files of our institution. All cases were histologically confirmed and the samples had been obtained from patients who were undergoing treatment. Histological typing was based on standard criteria (Tavassoli and Devilee, 2003). The histological grade was determined according to the System of Graduation of Scarff-Bloom-Richardson modified by Elston and Ellis (Elston et al., 1999).

Immunohistochemistry tests were performed at the Experimental Pathology Laboratory, CAISM, UNICAMP, to determine ER and PR protein expression. Four-micrometer sections, which were previously fixed on $10 \%$ neutral buffered formalin, were evaluated with the following antibodies: 1D5 (DAKO, Carpinteria, CA, USA) diluted 1:300 and PGR636 (NOVOCASTRA, New Castle, UK) diluted 1:100. Briefly, after being deparaffinized and gradually hydrated, non-specific sites were blocked with $10 \% \mathrm{H}_{2} \mathrm{O}_{2}$. Antigenic retrieval was performed with $10 \mathrm{mM}$ citrate buffer, $\mathrm{pH} 6.0$, for $30 \mathrm{~min}$ at $95^{\circ} \mathrm{C}$. Antibody incubation was carried out in two steps, primary antibody for $30 \mathrm{~min}$ at $37^{\circ} \mathrm{C}$ then overnight at $4^{\circ} \mathrm{C}$. Next day, the slides were automated-washed three times with PBS, dried with filter paper and re-incubated with the secondary antibody (LSAB - DAKO) for $30 \mathrm{~min}$ at $37^{\circ} \mathrm{C}$. Slides were then kept in PBS while DAB (diaminobenzidine - Sigma) was prepared. Samples were allowed to be stained with DAB for $5 \mathrm{~min}$ at $37^{\circ} \mathrm{C}$. After being washed in running distilled water, slides were counterstained with Mayer's hematoxylin for 30-60 $\mathrm{s}$ and, after dehydration, were ready to be mounted with permanent mounting media. All slides were evaluated by a pathologist. A cut-off value of $10 \%$ or more positively stained cells per 10 high-power fields was considered as ER- or PR-positive expression.

\section{RESULTS}

Results are summarized in Table 2. Eighty-three women had invasive ductal carcinoma and 11 had other histological types (lobular carcinoma ( 3 cases), metaplastic carcinoma (2 cases), medullary carcinoma ( 3 cases), papillary carcinoma ( 2 case) and mucinous carcinoma (1 case). In our results, $X R C C 1 \mathrm{Arg} / \mathrm{Gln}$ and $\mathrm{Gln} / \mathrm{Gln}$ was associated with the ductal subtypes of breast carcinomas $(\mathrm{P}=0.02)$.

Among the 83 cases of ductal carcinoma, histological grade was evaluated in 76 . Two cases were grade 1,35 cases were grade 2 and 39 cases were grade 3 . Grades 1 and 2 were grouped together for the purposes of statistical analysis. The association of XPD-Lys $751 \mathrm{Gln}$ genotypes with histological grade was statistically significant $(\mathrm{P}=0.05)$. No cases of the $G \ln /$ Gln genotype presented histological grade 3.

No statistically significant association was found between ER and PR expression and the genotypes of the polymorphisms of the RAD51, XPD, XRCC1, and XRCC3 genes. The $G \ln / G \ln$ genotypes of the XRCC1 genes and the Met/Met genotype of the XRCC3 gene had odds ratios of 2.6 and 2.8, respectively, for the analysis of ER expression. However, in both situations, no statistical significant correlations were observed (Table 2). With respect to the analysis of PR expression, the $G \ln / G \ln$ genotype of the XRCC1 gene had an odds ratio of 2.8, but no statistical differences were found (Table 2). 
DNA repair polymorphisms and breast cancer risk

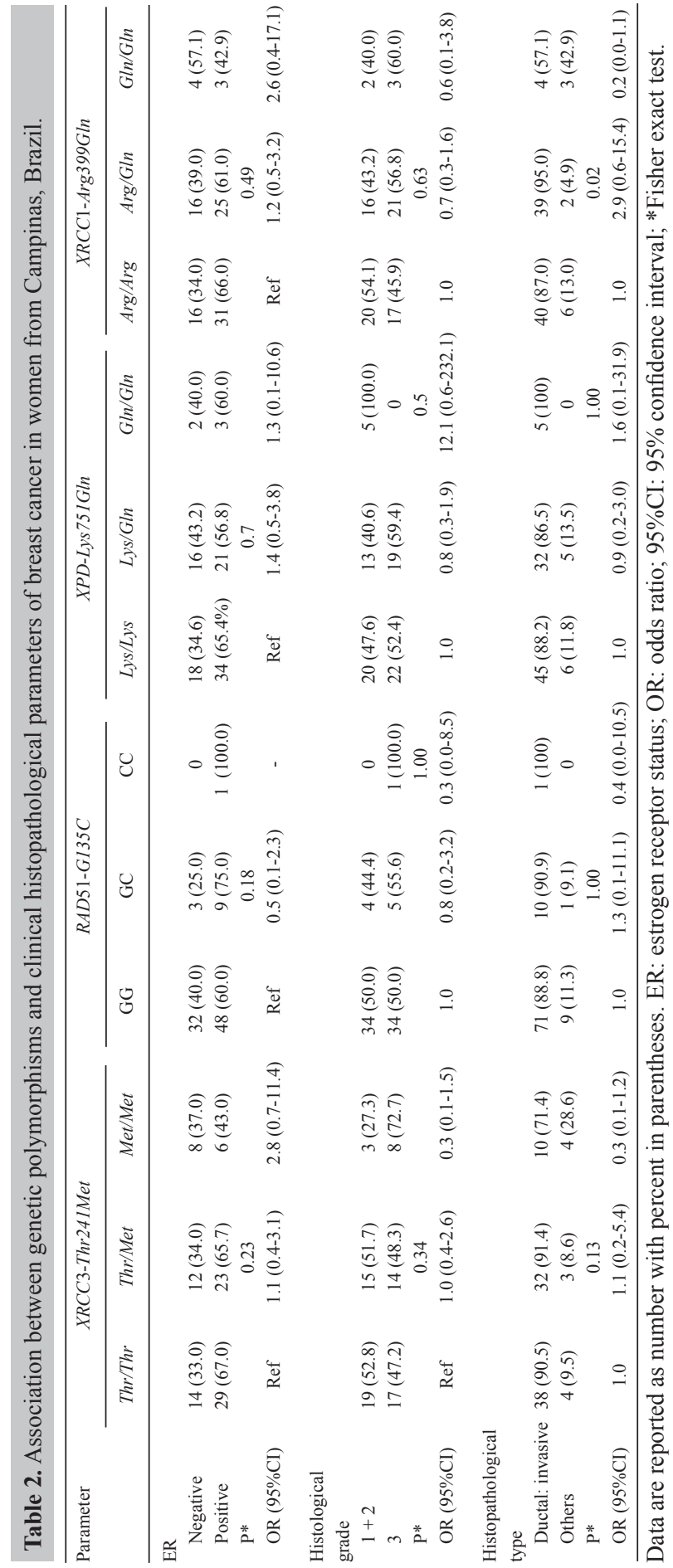




\section{DISCUSSION}

In this study, we aimed to verify a possible association between DNA repair gene polymorphisms $(X R C C 1, X P D, X R C C 3$, and $R A D 51)$ with histological characteristics and hormone receptor expression in women with breast cancer.

Polymorphisms in breast cancer susceptibility genes with low-penetrance, but present in a high percentage of individuals, have been shown to contribute to breast tumorigenesis in combination with exogenous and endogenous exposures (Rothman et al., 2001). More than 70 human genes have been described to be directly involved in the five major pathways of DNA repair, including chromosomal location and cDNA sequencing analysis. However, further data are yet to be gathered concerning the precise functions of these genes and their role in human health.

We had previously shown XRCC1-Arg399Gln as an important polymorphism related to sporadic breast cancer susceptibility, as well as RAD51-G135C polymorphism as a real risk modifier in familial breast cancer cases in a Portuguese population (Costa et al., 2007). However, in another study of the Brazilian population (Dufloth et al., 2005), an association between the case groups and the control group for any of the polymorphisms analyzed, and also between the breast cancer and family history group and the sporadic breast cancer group were not found. Sample sizes of women with breast cancer, whether familial or sporadic, were insufficient to show any small true differences between the groups. By the other hand, it has to be considered that currently there is no clear consensus regarding the association of these polymorphisms with breast cancer risk. Considering the data available, it can be conjectured that if there is any risk association between these single-nucleotide polymorphisms and breast cancer, this risk might not be high.

In this study, there was no sample selection based on histological type, and we observed that women with the $X R C C 1$ polymorphisms showed a relationship with the ductal subtype of breast cancer $(P=0.02)$. Another finding to be remarked is that all cases of $\mathrm{Gln} /$ Gln XPD genotype carriers had ductal carcinomas with a low histological grade. Xeroderma pigmentosum complementation group D (XPD) encodes a helicase that participates in both NER and basal transcription as part of the transcription factor IIH (Clarkson and Wood, 2005). Mutations destroying enzymatic function of the XPD protein are manifested clinically in combinations of three severe syndromes, Cockayne syndrome, xeroderma pigmentosum and trichothiodystrophy depending on the location of the mutation (Clarkson and Wood, 2005). Because XPD is important in multiple cellular tasks and XPD mutations rarely result in genetic diseases, $X P D$ polymorphisms may operate as genetic susceptibility factors. Nevertheless, the polymorphisms in $X P D$ genes are only weakly associated with breast cancer (Dufloth et al., 2005; Metsola et al., 2005; Brewster et al., 2006).

The association of histopathological cancer type with a positive family history for breast cancer is an issue with increased interest which could be also associated with specific molecular profiles of breast cancer. The basal-like subtypes are much more likely to present a higher percentage of cases classified as triple negative breast cancer than the other types. Basal-like cancer preferentially affects young and African-American women, has high histological grade and has more aggressive clinical behavior (Reis-Filho and Tutt, 2008). In the same way, hereditary breast carcinomas have an expression profile that is different from that of sporadic breast carcinomas, and is characterized by a higher histological grade (III), higher proliferative index, absence of ER and HER2 expression, and increased expression and co-ex- 
pression of basal markers, a fact that characterizes these carcinomas as being more aggressive (Lakhani, 1999; Elston et al., 1999; Lakhani et al., 2002; Matos et al., 2005). ER-negative status of the breast cancers is an intrinsic property of the tumor and contributes to subtype them in most aggressive tumors which have a worsened prognosis (Foulks et al., 2004). Thus, based on the results of this study, we hypothesize that patients who present the XRCC1-Arg399Gln and the $X P D$-Lys $751 G \ln$ polymorphisms could be a subgroup of low grade cancers that in general are sporadic and not hereditary. Additionally, relatively common low-penetrance cancer susceptibility genes considered together with endogenous and lifestyle risk factors, are likely to account for most cases of sporadic breast cancer, which are the most frequent form of the disease (Rebbeck, 1999; Johnson-Thompson and Guthrie, 2000).

Our results showed no statistical association between the $X R C C 1, X P D, X R C C 3$, and $R A D 51$ gene polymorphisms and ER or PR expression. Nevertheless, the sample size had insufficient statistical power to provide conclusive answers with respect to the association between these gene polymorphisms and negative ER expression. Gene polymorphisms that are part of the steroid hormone pathways may alter the levels and/or effects of endogenous hormones, and therefore influence breast cancer risk (de Jong et al., 2002). Taken together, a number of studies have evaluated the association of polymorphisms in low-penetrance genes such as $X R C C 3, P R, E R, X R C C 1$, and $B R C A 2$ with increased or decreased breast cancer risk (Smith et al., 2003; Dufloth et al., 2005; Lakhani et al., 2005; Costa et al., 2007, 2008). However, other studies (Enger et al., 2000; McCredie et al., 2003; Ma et al., 2006) have failed to find any significant differences in the profile of risk factors according to breast cancer subtypes.

In conclusion, the $X R C C 1$ genotype is associated with ductal carcinoma and $X P D$ genotypes with low histological grade, which is the most frequent pattern of sporadic breast carcinomas. Our findings suggest that the analysis of pathobiological features, together with genetic polymorphisms, may contribute to better understand the mechanisms of this disease by evaluating possible interactions between these genotypes and well-established risk factors for breast cancer.

Investigations regarding genotype distribution of DNA repair polymorphism will need to address questions of overlapping functions, signal pathways, and breast cancer risk as well as to consider possible treatment outcome effects as many of those polymorphisms have been shown to be also related to potential treatment predictor targets.

\section{ACKNOWLEDGMENTS}

Research supported by Coordenação de Aperfeiçoamento de Pessoal de Nível Superior (CAPES, BEX 244802-5), Brazil, Fundo de Apoio ao Ensino e Pesquisa da Universidade Estadual de Campinas (UNICAMP), Brazil, and Fundação Luso-Americana para o Desenvolvimento (FLAD, L-V-172/2002), Portugal.

\section{REFERENCES}

Althuis MD, Fergenbaum JH, Garcia-Closas M, Brinton LA, et al. (2004). Etiology of hormone receptor-defined breast cancer: a systematic review of the literature. Cancer Epidemiol. Biomarkers Prev. 13: 1558-1568.

Brewster AM, Jorgensen TJ, Ruczinski I, Huang HY, et al. (2006). Polymorphisms of the DNA repair genes XPD (Lys751Gln) and XRCC1 (Arg399Gln and Arg194Trp): relationship to breast cancer risk and familial predisposition to breast cancer. Breast Cancer Res. Treat. 95: 73-80.

Clarkson SG and Wood RD (2005). Polymorphisms in the human XPD (ERCC2) gene, DNA repair capacity and cancer 
susceptibility: an appraisal. DNA Repair 4: 1068-1074.

Costa S, Pinto D, Pereira D, Rodrigues H, et al. (2007). DNA repair polymorphisms might contribute differentially on familial and sporadic breast cancer susceptibility: a study on a Portuguese population. Breast Cancer Res. Treat. 103: 209-217.

Costa S, Pinto D, Pereira D, Rodrigues H, et al. (2008). XRCC1 Arg399Gln and RAD51 5'UTR G135C polymorphisms and their outcome in tumor aggressiveness and survival of Portuguese breast cancer patients. Breast Cancer Res. Treat. 109: 183-185.

de Jong MM, Nolte IM, te Meerman GJ, van der Graaf WT, et al. (2002). Genes other than BRCA1 and BRCA2 involved in breast cancer susceptibility. J. Med. Genet. 39: 225-242.

Dowsett M and Ashworth A (2003). New biology of the oestrogen receptor. Lancet 362: 260-262.

Dufloth RM, Costa S, Schmitt F and Zeferino LC (2005). DNA repair gene polymorphisms and susceptibility to familial breast cancer in a group of patients from Campinas, Brazil. Genet. Mol. Res. 4: 771-782.

Elston CW, Ellis IO and Pinder SE (1999). Pathological prognostic factors in breast cancer. Crit. Rev. Oncol. Hematol. 31: 209-223.

Enger SM, Ross RK, Paganini-Hill A, Carpenter CL, et al. (2000). Body size, physical activity, and breast cancer hormone receptor status: results from two case-control studies. Cancer Epidemiol. Biomarkers Prev. 9: 681-687.

Foulks WD, Metacalfe K, Sun P, Hanna WM, et al. (2004). Estrogen receptor status in BRCA1- and BRCA2-related breast cancer. Clin. Cancer Res. 10: 2029-2034.

Gruvberger S, Ringner M, Chen Y, Panavally S, et al. (2001). Estrogen receptor status in breast cancer is associated with remarkably distinct gene expression patterns. Cancer Res. 61: 5979-5984.

Johnson-Thompson MC and Guthrie J (2000). Ongoing research to identify environmental risk factors in breast carcinoma. Cancer 88: 1224-1229.

Lakhani SR (1999). The pathology of familial breast cancer: morphological aspects. Breast Cancer Res. 1: 31-35.

Lakhani SR, Jacquemier J, Sloane JP, Gusterson BA, et al. (1998). Multifactorial analysis of differences between sporadic breast cancers and cancers involving BRCA1 and BRCA2 mutations. J. Natl. Cancer Inst. 90: 1138-1145.

Lakhani SR, Van Den Vijver MJ, Jacquemier J, Anderson TJ, et al. (2002). The pathology of familial breast cancer: predictive value of immunohistochemical markers estrogen receptor, progesterone receptor, HER-2, and p53 in patients with mutations in BRCA1 and BRCA2. J. Clin. Oncol. 20: 2310-2318.

Lakhani SR, Reis-Filho JS, Fulford L, Penault-Llorca F, et al. (2005). Prediction of BRCA1 status in patients with breast cancer using estrogen receptor and basal phenotype. Clin. Cancer Res. 11: 5175-5180.

Ma H, Bernstein L, Pike MC and Ursin G (2006). Reproductive factors and breast cancer risk according to joint estrogen and progesterone receptor status: a meta-analysis of epidemiological studies. Breast Cancer Res. 8: R43.

Matos I, Dufloth R, Alvarenga M, Zeferino LC, et al. (2005). p63, cytokeratin 5, and P-cadherin: three molecular markers to distinguish basal phenotype in breast carcinomas. Virchows Arch. 447: 688-694.

McCredie MR, Dite GS, Southey MC, Venter DJ, et al. (2003). Risk factors for breast cancer in young women by oestrogen receptor and progesterone receptor status. Br. J. Cancer 89: 1661-1663.

Metsola K, Kataja V, Sillanpaa P, Siivola P, et al. (2005). XRCC1 and XPD genetic polymorphisms, smoking and breast cancer risk in a Finnish case-control study. Breast Cancer Res. 7: R987-R997.

Murphy L, Cherlet T, Lewis A, Banu Y, et al. (2003). New insights into estrogen receptor function in human breast cancer. Ann. Med. 35: 614-631.

Noruzinia M, Coupier I and Pujol P (2005). Is BRCA1/BRCA2-related breast carcinogenesis estrogen dependent? Cancer 104: $1567-1574$.

Rebbeck TR (1999). Inherited genetic predisposition in breast cancer. A population-based perspective. Cancer 86: 2493-2501.

Reis-Filho JS and Tutt AN (2008). Triple negative tumours: a critical review. Histopathology 52: 108-118.

Rothman N, Wacholder S, Caporaso NE, Garcia-Closas M, et al. (2001). The use of common genetic polymorphisms to enhance the epidemiologic study of environmental carcinogens. Biochim. Biophys. Acta 1471: C1-C10.

Smith TR, Levine EA, Perrier ND, Miller MS, et al. (2003). DNA-repair genetic polymorphisms and breast cancer risk. Cancer Epidemiol. Biomarkers Prev. 12: 1200-1204.

Tavassoli FK and Devilee P (2003). World Health Organization Classification of Tumours: Pathology and Genetic of Tumours of the Breast and Female Genital Organs. IARC Press, Lyon. 